\title{
Sifat Kimia dan Fisik Engay Food Berbasis Ikan Kembung dengan Penambahan Kedelai Hitam
}

\author{
Chemical and Physical Properties of Mackerel-Based Engay Food with The Addition of \\ Black Soybeans
}

\section{Anissa I. Cahyati, Nurrahman*, Siti Aminah}

Program Studi Teknologi Pangan, Universitas Muhammadiyah Semarang, Jl. Kedungmundu Raya No. 18 Semarang, Indonesia

*Penulis korespondensi: Nurrahman, nurrahman@unimus.ac.id

Tanggal submisi: 8 September 2021; Tanggal penerimaan: 4 Januari 2022; Tanggal publikasi: 29 Januari 2022

\begin{abstract}
Engay food is a type of food with a distinctively soft texture that is easy to swallow. This product is classified as a texture-modified food group. The primary ingredient used is mackerel fish, with the added nutritional benefit provided by black soybeans. The purpose of this research was to determine the effect of adding various concentrations of black soybeans on the physical and chemical characteristics of material-based engay food. A completely randomized experimental design was used in this study, which included $200 \mathrm{~g}$ of mackerel meat formulation and varying amounts of black soybean flour $(0,5,10,15$, and 20\%). Antioxidant activity, texture, and color were all determined during this study. The results indicated that increasing the concentration of black soybeans had a substantial effect on the chemical and physical properties of engay food made with mackerel. The greater the amount of black soybean added to the formulation, the higher the antioxidant activity, the lower the cohesiveness and gumminess, and the lower brightness of the yellow-red hue.
\end{abstract}

Keywords: Black soybean; chemical; engay food; mackerel fish; physical

(c) The Authors. Publisher Universitas Pattimura. Open access under CC-BY-SA license.

\begin{abstract}
ABSTRAK
Engay food adalah salah satu produk pangan dengan karakeristik tekstur yang lunak sehingga mudah ditelan. Produk ini termasuk dalam dalam kelompok makanan modifikasi tekstur. Bahan utama yang digunakan adalah ikan kembung dengan penambahan kedelai hitam yang diketahui berpotensi untuk meningkatkan nilai gizi. Tujuan penelitian ini untuk mengetahui pengaruh penambahan kedelai hitam terhadap karakteristik kimia dan fisik dari engay food berbasis ikan kembung. Rancangan yang digunakan adalah rancangan acak lengkap dengan formulasi ikan kembung $200 \mathrm{~g}$ dan penambahan tepung kedelai hitam sebanyak 0,5,10, 15, dan 20\%. Analisis yang dilakukan yaitu aktivitas antioksidan, tekstur dan warna. Hasil penelitian menunjukkan bahwa ada pengaruh penambahan konsentrasi kedelai hitam terhadap karakteristik kimia dan fisik dari engay food berbasis ikan kembung. penambahan kedelai hitam yang semakin banyak dalam engay food akan meningkatkan nilai aktivitas antioksidan, menurunkan nilai cohessiveness, adhesion, dan gumminess, akan tetapi menurunkan kecerahan dengan jenis warna yellow-red.
\end{abstract}

Kata Kunci: Engay food; fisik; ikan kembung; kedelai hitam; kimia

(C) Penulis. Penerbit Universitas Pattimura. Akses terbuka dengan lisensi CC-BY-SA.

\section{PENDAHULUAN}

Disfagia merupakan kelainan dimana seseorang mengalami kesulitan dalam menelan makanan (Afrida, 2017). Menurut Nayoan (2017), penderita disfagia 7-22\% adalah dewasa di atas 50 tahun, atau biasa disebut dengan usia lanjut. Sulitnya dalam proses menelan ini dapat menyebabkan banyak orang usia lanjut mengalami kekurangan gizi hingga menimbulkan beberapa komplikasi salah satunya adalah kematian (Tarihoran, 2017). Kebutuhan gizi laki-laki usia lanjut yang harus terpenuhi yaitu, protein minimal $64 \mathrm{~g}$, karbohidrat sebesar 235 sampai 340 g, kebutuhan lemak pada lansia 45-60 g, sedangkan untuk lansia wanita membutuhkan protein sebesar $58 \mathrm{~g}$ per hari, 
karbohidrat sebesar 200 sampai $280 \mathrm{~g}$ per hari, dan lemak sebesar 40 sampai $50 \mathrm{~g}$ untuk perempuan setiap harinya (AKG, 2019). Salah satu cara pemenuhan gizi tersebut dengan memberikan asupan makanan yang telah dilakukan modifikasi pada tekstur (TMF).

Texture modified food merupakan suatu modifikasi pada tekstur pangan yang ditujukan untuk memudahkan proses penelanan. Selain dikenal dengan texture modified food, modifikasi ini juga dikenal dengan sebutan engay food khususnya di negara Jepang. Menurut Aguilera \& Park (2016) istilah ini mengacu pada makanan yang memiliki tekstur yang lembut karena proses pengecilan partikel dari makanan tersebut. Ada beberapa persyaratan dari tekstur engay food yang perlu untuk diperhatikan yaitu, lembut, lembab, mudah hancur, dan yang paling penting adalah mudah untuk ditelan (Sungsinchai et al., 2019). Pembuatan dari texture modified food ini untuk mengatasi resiko buruk pada lansia yang mengalami kondisi disfagia. Menurut Torres et al. (2018), dengan texture modified food, komplikasi yang diakibatkan oleh disfagia dapat dicegah dan dibatasi. Pemenuhan kebutuhan gizi tersebut, dapat dilakukan dengan mengkonsumsi makanan yang telah dimodifikasi teksturnya. Milles et al. (2020) menyatakan bahwa, texture modified food mampu meningkatkan asupan gizi serta menaikkan berat badan lansia penderita kelainan disfagia.

Bahan utama yang biasa digunakan dalam pembuatan engay food adalah daging sapi, ayam, dan ikan salmon namun, karena harga yang cenderung tinggi maka, dalam pembuatan produk engay food saat ini menggunakan ikan kembung sebagai bahan dasarnya. Hal ini dikarenakan dalam ikan kembung terdapat kandungan gizi yang sangat baik untuk memenuhi sebagian besar unsur kesehatan (Nalendrya et al., 2016).

Ikan kembung adalah salah satu jenis ikan laut yang paling disukai oleh masyarakat di Indonesia, karena mudah untuk ditemukan di pasar dengan harga terjangkau serta memiliki sifat sensoris yang enak, lezat, dan gurih (Thariq et al., 2014). Ikan kembung juga memiliki beberapa kandungan yang baik apabila dikonsumsi seperti protein $22 \mathrm{~g}$, lemak $1 \mathrm{~g}$, fosfor $200 \mathrm{mg}$, kalsium 20 $\mathrm{mg}$, besi $1 \mathrm{~g}$, vitamin A 30 SI dan vitamin B1 0,05 mg (Thariq et al., 2014). total lemak ikan kembang sebesar $70 \%$, terdiri dari asam lemak omega 3 (Suroso et al., 2018) dan omega 6 (Nalendrya et al., 2016). Kandungan tersebut dapat membantu dalam menjaga sistem kekebalan tubuh dan juga mem- bantu menjaga daya ingat, penglihatan, dan mental seseorang (Diana, 2012).

Menurut Sungsinchai et al. (2019), selain tekstur, hal lain yang perlu diperhatikan dalam pembuatan engay food adalah kandungan nutrisinya dan juga komponen penting lainnya. Maka, untuk memperkaya nutrisi perlu dilakukan penambahan kedelai hitam ke dalam produk engay food. Menurut penelitian Kasih \& Murtini (2017) dapat diketahui bahwa penambahan kedelai hitam ke dalam produk bubur dapat meningkatkan nilai nutrisi dari produk.

Kedelai hitam merupakan salah satu bijibijian dengan kandungan yang sangat baik bagi tubuh (Kurniasih et al., 2013) akan tetapi, nilai penggunaan kedelai hitam pun masih sangat minim. Menurut Fawwaz et al. (2017) dan Nurrahman (2015), salah satu kandungan dalam kedelai hitam yang sangat baik adalah antioksidan yang berupa antosianin dan isoflavon. Kandungan antosianin dari kedelai hitam ini lebih tinggi bila dibandingkan dengan kedelai kuning. Hal tersebut dikarenakan kandungan antosianin pada kedelai kuning cenderung tidak terdeteksi sedangkan kandungan isoflavonenya masih di bawah kedelai hitam (Nurrahman, 2015).

Beberapa kelebihan dari isoflavon yang terkandung dalam kedelai hitam yaitu dapat menghambat stres oksidatif, menghambat sel kanker, serta dapat menginduksi enzim detoksifikasi (Hasanah et al., 2019). Selain itu, beberapa manfaat dari mengkonsumsi kedelai hitam menurut Loi (2018) adalah dapat menurunkan kolestrol, melancarkan pencernaan, serta mencegah penyakit terkait menepouse. Oleh sebab itu, kedelai hitam sangatlah baik bila ditambahkan ke dalam engay food mengingat sebagian besar penderita disfagia adalah lansia.

Penambahan kedelai hitam serta berbagai pengolahan yang dilakukan mempengaruhi sifat kimia dan fisik dari engay food sehingga, pada penelitian ini bertujuan untuk mengkarakteristik sifat-sifat kimia dan fisik engay food berbasis ikan kembung sebagai akibat penambahan kedelai hitam.

\section{BAHAN DAN METODE}

\section{Bahan}

Bahan yang digunakan dalam pembuatan engay food: kedelai hitam varietas Detam-1 yang didapatkan melalui BALITKABI Malang. Ikan kembung dan kentang kuning diperoleh dari Pasar Pedurungan Semarang. 


\section{Metode Penelitian}

\section{Persiapan Bahan Tepung Kedelai Hitam (Agume et al., 2017)}

Penyortiran biji kedelai hitam, pencucian, perendaman selama 12 jam dalam suhu ruang, pengupasan kulit, blanching pada suhu $80^{\circ} \mathrm{C}$, pengeringan $60^{\circ} \mathrm{C}$ selama 7 jam menggunakan pengering kabinet (Unimus, Indonesia), pengecilan ukuran menggunakan crusher (Cosmos, Indonesia) dan pengayakan dengan ayakan 100 mesh.

\section{Persiapan Bahan Ikan dan Kentang}

Ikan yang didapatkan dari pasar dilakukan pencucian hingga bersih dan dilakukan sortasi dengan membuang kulit insang, kepala, ekor, dan duri. Begitu pula dengan kentang, kentang yang di dapat dari Pasar Pedurungan dilakukan pencucian hingga bersih. Berikutnya dilakukan sortasi untuk memisahkan kulit dari dagingnya, kemudian dikukus, dan dihaluskan.

\section{Pembuatan engay food (modifikasi Viganó et al.. 2011)}

Pengolahan engay food berbasis ikan kembung dengan modifikasi (Viganó et al. 2011). Ikan kembung yang sudah bersih selanjutnya dihaluskan dan dihomogenisasi dengan kedelai hitam dalam bentuk tepung dengan variasi konsentrasi yaitu, 0 , 5 , 10, 15, dan 20\%, menggunakan alat food processor tipe HR 7627 (Phillip, Indonesia). Bahan tambahan yang digunakan merica $2 \%$, garam $1 \%$ (Revina, Indonesia), CMC 0,5\% (Kupu-kupu, Indonesia), dan kentang $10 \%$. Persentase berdasar pada bahan utama yaitu, ikan kembung. Selanjutnya dilakukan pemanasan dengan suhu $85^{\circ} \mathrm{C}$ dalam waktu 25 menit dilanjutkan dengan proses pendinginan hingga suhu menjadi $40^{\circ} \mathrm{C}$ untuk dilakukan pencetakan. Tahapan terakhir pemanggangan dilakukan dalam suhu $95^{\circ} \mathrm{C}$ selama 10 menit menggunakan Teflon (Maxim, Indonesia).

\section{Analisis Aktivitas Antioksidan (Xu \& Chang, 2007)}

Sampel sebanyak 0,5 g dimasukkan dalam tabung reaksi. Menambahkan $10 \mathrm{~mL}$ methanol (Merck, USA) ke dalam tabung reaksi berisi sampel dan ditutup dengan kertas aluminium foil untuk divortex selama 1 menit. Ekstraksi dilakukan selama 3 jam. 0,2 mL ekstrak dimasukkan ke tabung reaksi dan menambahkan $3,9 \mathrm{~mL}$ larutan DPPH (Sigma Aldrich, USA). Diamkan selama 30 menit dalam ruang gelap. Mengukur absorbansi larutan ekstrak dengan menggunakan spektrofotometer
UV-Vis (Amtast AMV 09, USA) panjang gelombang $517 \mathrm{~nm}$. Pembuatan blanko dengan menggunakan metanol yang diberi perlakuan seperti sampel. Aktivitas antioksidan dapat diketahui melalui perhitungan sebagai berikut:

$$
\% R S A=\frac{\text { abs blanko-abs sampel }}{\text { abs blanko }} \times 100 \%
$$

\section{Analisis Tekstur (Harahap et al., 2018)}

Uji kekerasan dilakukan dengan menggunakan alat texture analyzer CT-3 (Brookfield, Inggris). Sebelum menggunakan alat ini, perlu dilakukan pemasangan probe terlebih dahulu. Cara menggunakan alat ini dengan melakukan penekanan pada sampel hingga hasil kurva keluar. Kurva yang keluar merupakan profil dari tekstur sampel tersebut. Apabila nilai gaya dalam kurva semakin tinggi maka, menunjukkan bahwa tingkat kerenyahan tekstur semakin rendah.

\section{Analisis Kecerahan Warna (Kaemba et al., 2017)}

Uji kecerahan warna dilakukan dengan menggunakan alat chromameter WR10 (Fru, Cina). Sebelum digunakan alat perlu dilakukan kalibrasi terlebih dahulu dengan standar warna putih. Hasil derajat putih berupa $L^{*}, a^{*}$, dan $b^{*}$. Basis derajat putih digunakan sebagai standard dalam penggunaan alat. Uji alat dilakukan dengan menyalakan alat terlebih dahulu. Setelah menyala maka, alat ditempelkan pada permukaan sampel dan melakukan pencatatan pada hasil koordianat yang keluar.

\section{Rancangan Percobaan}

Metode yang digunakan yaitu eksperimental rancangan acak lengkap dengan lima taraf perlakuan penambahan konsentrasi tepung kedelai hitam yang berbeda yaitu $0,5,10,15$, dan $20 \%$ dari bahan dasar yaitu ikan kembung dengan pengulangan sebanyak lima kali.

\section{Analisis Data}

Data analisis karakteristik fisik dan kimia dari engay food berbasis ikan kembung yang ditambah kedelai hitam akan dilakukan uji menggunakan analisis variansi analisis keragaman satu arah dan lakukan uji lanjut menggunakan duncan test $(\alpha=0,05)$. 


\section{HASIL DAN PEMBAHASAN}

\section{Karakteristik Kimia}

\section{Aktivitas Antioksidan}

Antioksidan adalah senyawa yang dapat menghambat terjadinya reaksi oksidasi dari radikal bebas (Ramdhan et al., 2020). Hasil rerata nilai aktivitas antioksidan produk engay food berbasis ikan kembung dengan penambahan kedelai hitam dapat dilihat pada Gambar 1.

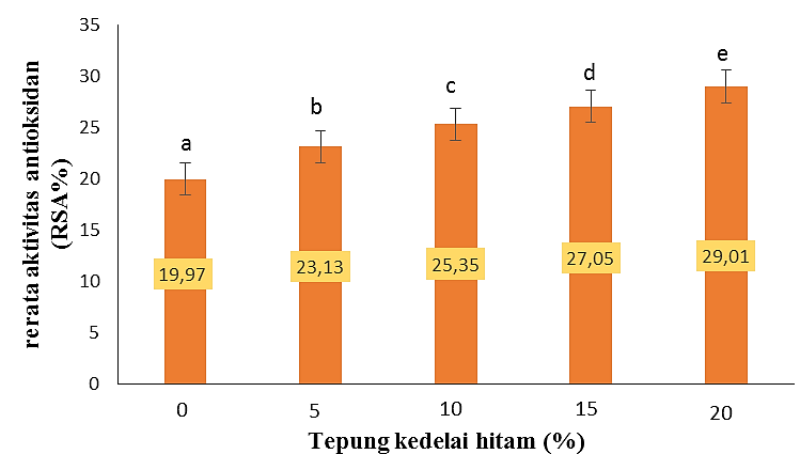

Gambar 1. Rerata nilai aktivitas antioksidan pada produk engay food berdasar penambahan konsentrasi tepung kedelai hitam

Hasil uji ragam menunjukkan nilai $p<0,05$ yang mana mengartikan bahwa, terdapat pengaruh penambahan kedelai hitam terhadap nilai aktivitas antioksidan produk engay food. Pada uji lanjut duncan menunjukkan bahwa terdapat perbedaan yang sangat signifikan pada tiap perlakuan.

Aktivitas antioksidan tertinggi dimiliki oleh produk engay food dengan penambahan kedelai hitam $20 \%$ yaitu sebesar $29,01 \%$ dan terendah pada penambahan kedelai hitam $0 \%$ yaitu sebesar 19,97\% (Gambar 1). Aktivitas antioksidan terus meningkat seiring dengan penambahan kedelai hitam. Hasil pada Gambar 1 sesuai dengan pernyataan Millah \& Anjani (2017), bahwa seiring dengan penambahan kedelai hitam maka, aktivitas antioksidan meningkat.

Peningkatan aktivitas antioksidan dikarenakan dalam kedelai hitam terdapat kandungan antosianin dan isoflavon (genisterin dan daidzein) yang cukup tinggi secara berurutan yaitu sebesar $222,49 \mathrm{mg} / 100 \mathrm{~g}, 0,65 \mathrm{mg} / \mathrm{g}$, dan $3,67 \mathrm{mg} / \mathrm{g}$ (Nurrahman, 2015). Sehingga semakin banyak tepung kedelai hitam yang ditambahkan akan semakin besar pula nilai aktivitas antioksidannya. Selain itu, vitamin $\mathrm{C}$ yang terkandung di dalam kentang merupakan salah satu golongan antioksidan (Putri \& Minerva, 2021). Vitamin C yang terkandung sebesar $35 \mathrm{mg} / 100 \mathrm{~g}$ (Fikarauza et al., 2019) sehingga, kentang juga ikut berkontribusi dalam memberikan nilai pada aktivitas antioksidan.

\section{Karakteristik Fisik}

\section{Tekstur}

Tekstur memiliki berbagai aspek penilaian diantaranya yaitu, cohessiveness, adhesion, dan gumminess. Nilai gumminess merupakan gabungan dari nilai adhesion dan cohessivenes.

Cohessivnes merupakan tingkat kekompakkan dari suatu produk. Semakin tinggi nilai cohessivnes suatu produk menandakan bahwa keutuhan atau kekompakkan produk tersebut semakin baik (Iswara et al., 2019). Hasil rerata nilai cohessivnes pada produk engay food berbasis ikan kembung dengan penambahan kedelai hitam dapat dilihat pada Gambar 2.

Rerata nilai cohessivnes tertinggi dimiliki oleh produk engay food dengan penambahan tepung kedelai hitam $0 \%$ dan terendah pada penambahan tepung kedelai hitam sebanyak $20 \%$. Hal tersebut menunjukkan bahwa, semakin banyak penambahan konsentrasi kedelai hitam akan menurunkan nilai cohessivnes dari produk engay food. Semakin rendah nilai cohessivnes dimungkinkan karena tepung kedelai hitam tidak memiliki kandungan gluten, pati, amilopektin, maupun daya rekat seperti yang dimiliki oleh telur. Hal ini sesuai dengan pernyataan Fitriyani et al. (2017) bahwa semakin rendahnya kandungan gluten maupun pektin di dalam bahan maka, akan menurunkan nilai kekompakkan suatu produk.

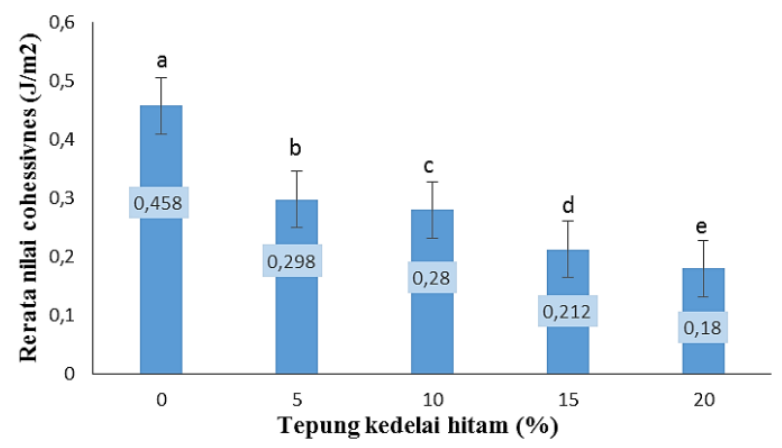

Gambar 2. Rerata nilai cohessivnes produk engay food berdasar penambahan konsentrasi tepung kedelai hitam

Hasil uji ragam menunjukkan nilai $p<0,05$ yang mana mengartikan bahwa, terdapat pengaruh penambahan kedelai hitam terhadap cohessivnes produk engay food. Pada uji lanjut duncan 
menunjukkan bahwa terdapat perbedaan yang sangat signifikan pada tiap perlakuan.

Besarnya daya yang dibutuhkan untuk menarik makanan dari permukaan merupakan makna dari adhesion (Haliza et al., 2012). Semakin tinggi nilainya menandakan bahwa produk tersebut memiliki kelengketan bahan yang semakin tinggi (Iswara et al., 2019). Hasil rerata nilai adhesion pada produk engay food berbasis ikan kembung dengan penambahan kedelai hitam dapat dilihat pada Gambar 3. Rerata tertinggi dimiliki oleh produk engay food dengan penambahan tepung kedelai hitam 0\% yaitu sebesar 0,516 mJ. Sedangkan nilai rerata terendah pada penambahan tepung kedelai hitam sebanyak $20 \%$ yaitu sebesar $0,076 \mathrm{~mJ}$

Gambar 3 menunjukkan bahwa, semakin banyak penambahan konsentrasi kedelai hitam akan menurunkan kelengketan dari produk engay food akan semakin berkurang. Semakin rendahnya kelengketan dari produk engay food ini dimungkinkan karena dalam tepung kedelai hitam tidak memiliki kandungan gluten seperti tepung terigu, pati, amilopektin, maupun daya rekat seperti hal nya telur. Hal tersebut sesuai dengan pernyataan Fridata et al. (2014) bahwa, rendahnya kandungan gluten pada suatu bahan akan menyebabkan produk menjadi lebih mudah hancur dan patah. Alasan tersebutlah yang menjadi penyebab kelengketan dari engay food akan berkurang seiring dengan penambahan kedelai hitam.

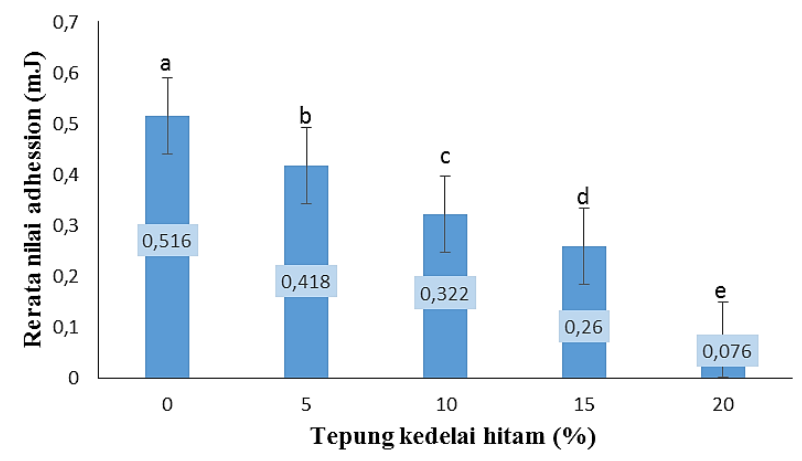

Gambar 3. Rerata nilai adhesion produk engay food berdasar penambahan konsentrasi tepung kedelai hitam

Hasil uji ragam menunjukkan nilai $p<0,05$ yang mana mengartikan bahwa, terdapat pengaruh penambahan kedelai hitam terhadap adhesion produk engay food. Pada uji lanjut duncan menunjukkan bahwa terdapat perbedaan yang sangat signifikan pada tiap perlakuan.

Menurut Wada (2017) standar engay food memiliki standard nilai adhesion yaitu antara 0,2 sampai 0,6 mJ. Hal tersebut menunjukkan bahwa nilai adhesion produk engay food dengan penambahan kedelai $20 \%$ tidak memenuhi standard engay food. Nilai adhesion selanjutnya dilakukan uji ragam dan menunjukkan nilai $p<0,05$ yang mana mengartikan bahwa, terdapat pengaruh penambahan kedelai hitam terhadap adhesion produk engay food.

Gumminess merupakan besarnya energi yang diperlukan dalam menghancurkan suatu makanan hingga dapat ditelan (Fitriyani et al., 2017). Hal tersebut menandakan bahwa, semakin rendah nilai dari gumminess maka, semakin kecil energi yang diperlukan dalam menghancurkan suatu makanan. Hasil rerata nilai gumminess pada produk engay food berbasis ikan kembung dengan penambahan kedelai hitam (Gambar 4). Rerata nilai gumminess tertinggi dimiliki oleh produk engay food dengan penambahan tepung kedelai hitam $0 \%$ yaitu sebesar $274.157 \mathrm{~N} / \mathrm{m}^{2}$. Sedangkan nilai rerata terendah pada penambahan tepung kedelai hitam sebanyak $20 \%$ yaitu sebesar $37.655 \mathrm{~N} / \mathrm{m}^{2}$.

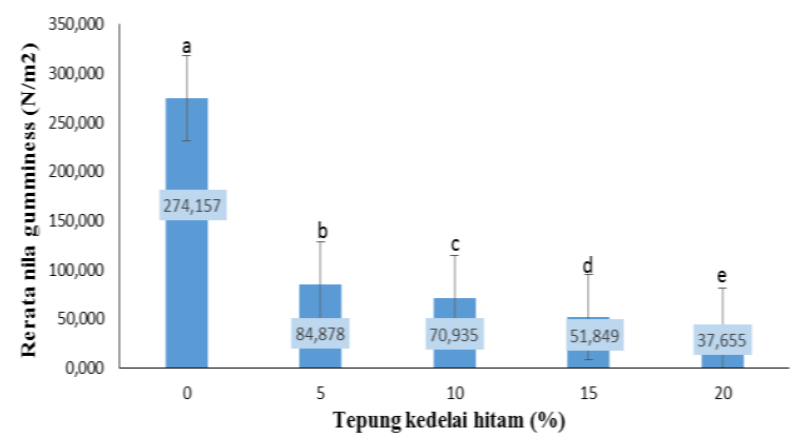

Gambar 4. Rerata nilai gumminess produk engay food berdasar penambahan konsentrasi tepung kedelai hitam

Hasil uji ragam menunjukkan nilai $p<0,05$ yang mana mengartikan bahwa, terdapat pengaruh penambahan kedelai hitam terhadap gumminess produk engay food. Pada uji lanjut duncan menunjukkan bahwa terdapat perbedaan yang sangat signifikan pada tiap perlakuan.

Gambar 4 menunjukkan bahwa, semakin banyak penambahan konsentrasi kedelai hitam akan menurunkan nilai gumminess dari produk engay food. Semakin rendahnya nilai gumminess ini dimungkinkan karena tepung kedelai hitam tidak memiliki kandungan gluten didalamnya seperti milik tepung terigu, pati, amilopektin, maupun daya rekat seperti yang dimiliki oleh telur dan tepung perekat lainnya. Hal tersebutlah yang menyebabkan produk menjadi kurang kenyal, kurang kompak dan lebih mudah hancur. Selain itu, sebelum dilakukan 
pengolahan bahan baku dilakukan pengecilan ukuran terlebih dahulu sehingga menyebabkan proses penghancuran lebih mudah.

Standar nilai gumminess dari engay food menurut Wada (2017) adalah di bawah $15000 \mathrm{~N} / \mathrm{m}^{2}$. Hal tersebut menunjukkan bahwa nilai gumminess produk sudah memenuhi standar engay food.

Secara keseluruhan dapat diketahui bahwa seiring dengan bertambahnya konsentrasi kedelai hitam yang ditambahkan maka, semakin menurun nilai cohessiveness, adhesion, dan gumminess produk engay food berbasis ikan kembung. Hal tersebut menunjukkan bahwa nilai cohessiveness, adhesion, dan gumminess saling berhubungan dimana, semakin rendahnya nilai cohessiveness maka, semakin rendah pula nilai adhesion serta gumminess-nya. Pernyataan tersebut tidak sesuai dengan hasil penelitian Haliza et al. (2012) yang menunjukkan bahwa semakin rendah nilai adhesion maka semakin tinggi nilai gumminess, akan tetapi pernyataan tersebut sesuai dengan pernyataan Indirato et al. (2012) bahwa semakin tinggi nilai cohessiveness maka semakin tinggi pula nilai gumminess produk begitu pula sebaliknya

Meskipun kekompakkan, kelengketan, serta kekenyalan dari produk ini berkurang seiring dengan penamabahan kedelai hitam, akan tetap, tekstur dari engay food masih terlihat tetap menyatu yang dimungkinkan karena dalam pembuatan engay food menggunakan CMC yang berperan sebagai thickener untuk menjaga stabilitas serta kepadatan dari produk. Hal ini sesuai dengan pernyataan dari Abdullah \& Mutia (2020) bahwa, CMC dapat membantu untuk menjaga kepadatan tekstur suatu produk. Selain itu, dalam pembuatan engay food juga menggunakan kentang yang memiliki kandungan amilosa serta amilopektin di dalamnya (Sjamsiah et al., 2017). Menurut Iswara et al. (2019), amilopektin memiliki sifat sebagai perekat sehingga, kentang juga berperan dalam menjaga cohessiveness, adhesion, dan gumminess produk engay food agar tetap terlihat menyatu.

\section{Kecerahan Warna}

Warna merupakan salah satu aspek penting dalam penilaian suatu produk terutama, makanan. Aspek warna ini menunjukkan tingkat kecerahan dan juga jenis warna dari suatu produk.

Nilai chroma merupakan nilai saturasi tingkatan terang. Apabila nilai chroma yang dihasilkan semakin kecil maka, menunjukkan kecerahan warna yang menurun (Swandari et al., 2017). Hasil rerata nilai chroma pada produk engay food berbasis ikan kembung dengan penambahan kedelai hitam dapat dilihat pada Gambar 5.

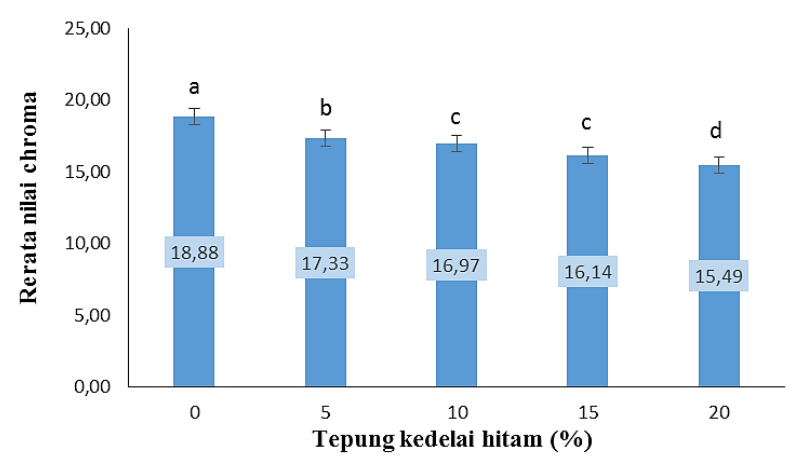

Gambar 5. Rerata nilai chroma pada produk engay food berdasar penambahan konsentrasi tepung kedelai hitam

Hasil uji ragam menunjukkan nilai $p<0,05$ yang mana mengartikan bahwa, terdapat pengaruh penambahan kedelai hitam terhadap nilai choma produk engay food. Pada uji duncan menunjukkan bahwa terdapat perbedaan yang sangat signifikan antar perlakuan 5 dan $10 \%$ dengan 0 , 15, dan $20 \%$.

Gambar 5 menunjukkan bahwa rerata nilai chroma terendah dimiliki oleh engay food dengan penambahan kedelai hitam 20\% yaitu sebesar 15,49. Nilai chroma tertinggi dimiliki oleh engay food dengan penambahan kedelai hitam $0 \%$ yaitu sebesar 18,88. Hal tersebut menunjukkan bahwa semakin banyak konsentrasi kedelai hitam yang ditambahkan menyebabkan kecerahan produk semakin menurun. Hal ini dimungkinkan karena adanya kulit kedelai hitam yang ikut tercampur dimana, kulit tersebut memiliki pigmen penyumbang warna yaitu antosianin (Pramitasari et al., 2017). Pengeringan yang dilakukan pada kedelai hitam sebelum ditepungkan juga dapat menjadi penyebab turunnya kecerahan dari tepung yang dihasilkan (Pratama \& Ayustaningwarno, 2015). Hal ini sesuai dengan penelitian Putri et al. (2018) yang menyatakan bahwa, seiring dengan banyaknya penambahan kedelai hitam akan menurunkan kecerahan dari produk.

Hue merupakan ketipisan warna yang menunjukkan derajat dari warna (Swandri et al., 2017). Hasil rerata nilai derajat hue pada produk engay food berbasis ikan kembung dengan penambahan kedelai hitam dapat dilihat pada Gambar 6.

Hasil uji ragam menunjukkan nilai $p<0,05$ yang mana mengartikan bahwa, terdapat pengaruh penambahan kedelai hitam terhadap nilai derajat warna produk engay food. Pada uji duncan menunjukkan bahwa terdapat perbedaan sangat 
signifikan antar perlakuan 15 dan $20 \%$ dengan 0,5 , dan $10 \%$.

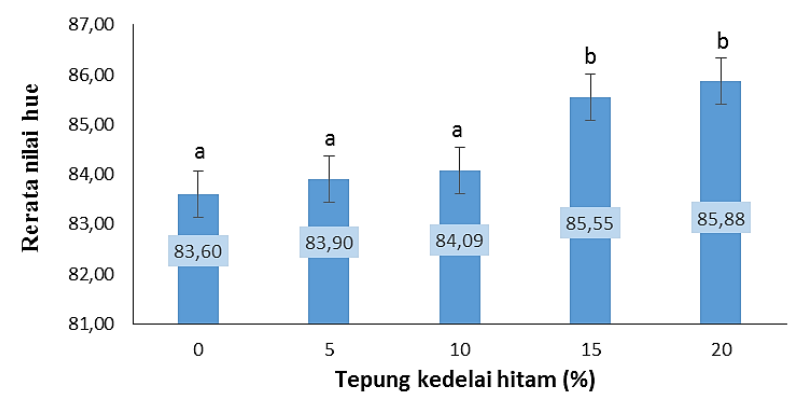

Gambar 6. Rerata nilai derajat hue pada produk engay food berdasar penambahan konsentrasi tepung kedelai hitam

Nilai hue dari Gambar 6 dapat diketahui berkisar antara 83,60 hingga 85,88. Hal ini menunjukkan bahwa produk engay food ini memiliki warna yellow-red. Menurut Hasbullah \& Umiyati (2017) nilai derajat hue 0 hingga 90 menunjukkan warna merah kekuningan. Warna tersebut didapatkan karena adanya kulit kedelai hitam yang mengandung antosianin ikut tercampur dalam produk (Pramitasari et al., 2017). Hal tersebut juga sesuai dengan pernyataan Pujilestari (2017) bahwa, antosianin memberikan warna merah oranye. Penambahan kentang dalam engay food juga memberikan kontribusi dalam memberikan warna. Kentang memiliki kandungan pigmen beta karotenoid sehingga dapat membeikan warna kekuningan pada produk engay food (Nareswara \& Anjani, 2016).

Gambar 5 dan Gambar 6 menunjukkan bahwa semakin tinggi penambahan tepung kedelai hitam ke dalam produk engay food maka, nilai chroma akan semakin menurun akan tetapi, nilai hue akan semakin meningkat. Hal tersebut menandakan bahwa, semakin banyak kedelai hitam yang ditambahkan maka, tingkat kecerahan warna akan semakin menurun dan jenis warna yang dihasilkan adalah yellow red dengan kecenderungan warna kekuningan. Hal tersebut sesuai dengan penelitian milik Kasih \& Murtini (2017) yang mendapatkan hasil bahwa seiring dengan penambahan kedelai hitam maka produk yang dihasilkan akan cenderung berwarna merah kekuningan.

\section{KESIMPULAN}

Berdasarkan penelitian yang telah dilakukan dapat disimpulkan bahwa, terdapat pengaruh dari penambahan konsentrasi kedelai hitam teradap karakteristik kimia, dan fisik dari engay food berbasis ikan kembung. Penambahan kedelai hitam yang semakin banyak dalam engay food akan meningkatkan nilai aktivitas antioksidan, menurunkan nilai cohessiveness, adhesion, dan gumminess, akan tetapi menurunkan kecerahan dengan jenis warna yellow-red.

\section{DAFTAR PUSTAKA}

Abdullah, F., \& Mutia, A.K. (2020). Pengaruh penambahan CMC (Carboxyl Methyl Cellullose) terhadap uji organoleptik otakotak ikan nike. Jurnal Pendidikan Teknologi Pertanian, 6(2), 171-180. https://doi.org/10.26858/jptp.v6i2.12963

Afrida. (2017). Effect of ingesting training towards dysphagia in stroke' patients in haji hospital and Makassar city hospital. Indonesian Contemporary Nursing Journal, 2(1), 13-20. https://doi.org/10.20956/icon.v2i1.3580

Aguilera, J.M., \& Park, D.J. (2016). Texturemodified foods for the elderly: status, technology, and oppurtunities. Journal Trends in Food Science and Food Technology, 57, 156-164. https://doi.org/10.1016/j.tifs.2016.10.001

Agume, A.S.N., Njintang, N.Y., \& Mbofung, C.M.F. (2017). Effect of soaking and roasting on the physicochemical and pasting properties of soybean flour. Foods, 6, 1-10. 10.3390/foods6020012

[AOAC] Association of Official Analytical Chemists. (2005). Official Methods of Analysis. Washington DC.

Burger, C., Kieswetter, E., Alber, R., Pfannes, U., Azevedo, U.A., \& Volkert, D. (2019). Texture modified diet in German nursing homes: availability, best practices, association with nursing home characteristics. BMC Geriatrics, 19(1), 1-11.

Diana, M.F. (2012). Omega 6. Jurnal Kesehatan Masyarakat, 7(1), 26-31. https://doi.org/10.24893/jkma.v7i1.104

Fawwaz, M., Muliadi, D.S., \& Muflihunna, A. (2017). Kedelai hitam (Glycine soja) terhidrolisis sebagai sumber flavonoid total. Jurnal Fitofarmaka Indonesia, 4(1), 195198. https://doi.org/10.33096/jffi.v4i1.227

Fikarauza, M., Agustina, R., \& Khathir, R. (2019). Kajian variasi ketebalan lapisan pengeringan kentang menggunakan tray dryer terhadap kualitas tepung kentang. Jurnal Ilmiah Mahasiswa Pertanian, 4(2), 339-348. https://doi.org/10.17969/jimfp.v4i2.10863 
Fitriyani, E. (2017). Tepung ubi jalar sebagai baha filler pembentuk tekstur bakso ikan. Jurnal Galung Tropika, 6, 19-32. http://dx.doi.org/10.31850/jgt.v6i1.197

Fizriani, A., Putri, N.E., \& Triandita, N. (2019). Sifat kimia dan sensori brownies berbahan baku tepung mocaf, jagung, dan kedelai hitam. Jurnal Teknologi Pangan, 2, 24-34. http://dx.doi.org/10.26418/jft.v2i2.40799

Fridata, I.G., Pranata, F.S., \& Purwijantiningsih. (2014). Kualitas biskuit keras kombinasi tepung ampas tahu dan bekatul beras merah. Jurnal Teknobiologi, 1-16.

Haliza, W., Kaiaku, S.I., \& Yuliani, S. (2012). Penggunaan mixture response surface methodology pada optimasi formulasi brownies berbasis tepung talas Banten (Xanthosoma undipes K. Koch) sebagai alternatif pangan sumber serat. Jurnal Pascapanen, 9(2), 96-106. http://dx.doi.org/10.21082/jpasca.v9n2.2012 $.96-106$

Harahap, S.E., Purwanto, A., Budijanto, S., \& Maharijaya, A. (2018). Karakterisasi kerenyahan dan kekerasan beberapa genotipe kentang (Solanum tuberosum L.) hasil pemuliaan. Jurnal Pangan, 26(3), 1-7. https://doi.org/10.33964/jp.v26i3.358

Hasanah, S.U., Wibowo, D.P., \& Sari, N.N. (2019). Total flavonoid levels in various varieties of soybean seeds (Glycine max) in Indonesia. Jurnal Ilmiah Farmako Bahari, 10(2), 132138.

Hasbullah, U.H.A.A., \& Umiyati, R. (2017). Perbandingan warna tepung suweg fase dorman dan vegetatif secara instrumental dan sensoris. Argisaintifika: Jurnal Ilmu-Ilmu Pertanian, 1(1), 64-69. https://doi.org/10.32585/ags.v1i1.40

Indirato, R., Nurhadi, B., \& Subroto, E. (2012). Kajian karakteristik tekstur (Texture profile analysis) dan organoleptik daging ayam asap berbasis teknologi asap cair tempurung kelapa. Jurnal Teknologi Hasil Pertanian, $5(2)$, 106-116. https://doi.org/10.20961/jthp.v0i0.13562

Iswara, J.A., Julianti, E., \& Nurminah, E. (2019). Karakteristik tekstur roti manis dari tepung, pati, serat, dan pigmen antosianin ubi jalar ungu. Jurnal Pangan dan Agroindustri, 7(4), 12-21.

http://dx.doi.org/10.21776/ub.jpa.2019.007. 04.2
Kaemba, A., Suryanto, E., \& Mamuja, C.F. (2017). Karakteristik fisiko-kimia dan aktivitas antioksidan beras analog dari sagu baruk (Arenga microcapha) dan ubi jalar ungu (Ipomea batatas L. poiret). Jurnal Ilmu dan Teknologi Pangan, 5(1), 74-81.

Kusbandari, A., \& Susanti, H. (2017). Kandungan beta karoten dan aktivitas antioksidan penangkapan radikal bebas terhadap DPPH (1,1-difenil 2-pikrilhidrazil) ekstrak buah belewah (Cucumis melo var. Cantalupensis L) secara spektrofotometri UV-Visibel. Jurnal Kimia Riset, 14(1), 37-42. https://doi.org/10.24071/jpsc.00562

Kasih, G.Z., \& Murtini, E.S. (2017). Inovasi bubur instan berbasis tepung kimpul (Xantoshoma sagittifolium) dan tepung kedelai hitam (Glycine soja). Jurnal Teknologi Pertanian, 18(3),

201-210. http://dx.doi.org/10.21776/ub.jtp.2017.018.0 3.20

Loi, H. (2018). Pengaruh pemberian minuman sari kacang kedelai hitam terhadap penurunan kadar kolesterol dan tekanan darah pada penderita hipertensi di wilayah kerja puskesmas lubuk pakam Skripsi. Medan: Politrknik Kesehatan Kemenkes Medan.

Miles, A., Liang, V., Sekula, J., Broadmore, S., Owen, P., Braakhuis, A.J. (2020). Texturemodified diets in aged care facilities: nutrition, swallow, safety, and mealtime experience. Australasian Journal on Ageing, 39(1), 31-39. 10.1111/ajag.12640

Millah, S., \& Anjani, G. (2017). Subtitusi tepung kedelai hitam pada mie basah untuk penderita hiperkolesterolemia. Journal of Nutrition College, 6(2), 156-163. https://doi.org/10.14710/jnc.v6i2.16904

Nareswara, A.R., \& Anjani, G. (2016). Studi tentang susu almond dan kentang sebagai alternatif minuman fungsional untuk anak autis. Journal of Nutrition College, 5(4), 269279. https://doi.org/10.14710/jnc.v5i4.16421

Nalendrya, I., Ilmi, I.M.B., \& Arini, F.A. (2016). Sosis ikan kembung (Rastrellier Kanagurta L.) sebagai pangan sumber Omega 3. Jurnal Aplikasi Teknoloi Pangan, 5(3), 71-75. http://dx.doi.org/10.17728/jatp.178

Nayoan, C.R. (2017). Gambaran penderita disfagia yang menjalani pemeriksaan fiberoptic endoscopic evaluation of swallowing di RSUP DR. Kariadi Semarang periode 20152016. Jurnal Kesehatan Tadulako, 3(2), 1-75. 
Nurrahman. (2015). Evaluasi komposisi zat gizi dan senyawa antioksidan kedelai hitam dan kedelai kuning. Jurnal Aplikasi Teknologi Pangan, 4(3), 89-93. http://dx.doi.org/10.17728/jatp.v4i3.133

Peraturan Menteri Kesehatan Republik Indonesia Nomor 28 tahun 2019. (2019). Angka Kecukupan Gizi yang Dianjurkan untuk Masyarakat Indonesia.

Pramitasari, R., Halim, G., \& Prasasty, V.D. (2017). Evaluasi sensori, nilai gizi, dan sifat fisik cookies kedelai hitam untuk ibu menyusui. Jurnal Pangan dan Gizi, 7(1), 1-8. https://doi.org/10.26714/jpg.7.1.2017.1-8

Pratama, S.H., \& Ayustaningwarno, F. (2015). Kandungan gizi, kesukaan, dan warna biskuit subtitusi tepung pisang dan kecambah kedelai. Journal of Nutrition College, 4(3), 252-258.

https://doi.org/10.14710/jnc.v4i3.10090

Pujilestari, T. (2015). Review: Sumber dan pemanfaatan zat warna alam untuk keperluan industri. Dinamika Kerajinan dan Batik, $32(2)$, 93-106. http://dx.doi.org/10.22322/dkb.v32i2.1365

Putri, H.S., \& Minerva, P. (2021). Kelayakan masker tepung kentang untuk perawatan kulit wajah jerawat. Junal Tata Rias dan Kecantikan, 3(1), 29-33.

Putri, R.H., Chandradewi, A., Sofiyatin, R., \& Darawati, M. (2018). Sifat organoleptik dan kandungan zat gizi biskuit berbasis bahan pangan lokal. Jurnal Kesehatan Prima, 12(1), 30-40. https://doi.org/10.32807/jgp.v4i1.131

Ramdhan, H., Baidah, D., Lestari, P.N., \& Yuliana, K.A. (2020). Aktivitas antioksidan ekstrak etanol 96\% daun, buah kulit terap (Artocarpus odorratissimus) menggunakan metode cuprac. Jurnal Ilmiah Ilmu Kefarmasian, 7(1), 7-12. https://doi.org/10.22236/farmasains.v7i1.4331

Sjamsiah., Saokani, J., \& Lismawati. (2018). Karakteristik edible film dari pati kentang (Solanum tuberosum L.) dengan penambahan gliserol. Jurnal Al-Kimia, 5(2): 181-192. https://doi.org/10.24252/al-kimia.v5i2.3932
Sungsinchai, S., Niamnuy, C., Wattanapan, P., Charoenchaitrakool, M., \& Devahastin, S. (2019). Texture modification technologies and their opportunities for the production of dysphagia foods: a review. Journal Comprehensive Reviews in Food Science and Food Safety, 18(6), 1898-1912. https://doi.org/10.1111/1541-4337.12495

Swandari, T., Basunanda, P., \& Purwantoro, A. (2017). Penggunaan alat sensor warna untuk menduga derajat dominasi gen penyandi karakter warna buah cabai hasil persilangan. Jurnal Agroteknologi, 1(2), 40-49.

Tarihoran, Y. (2019). Pengaruh shaker exercise terhadap kemampuan menelan pada pasien stroke dengan disfagia di rumah sakit Kota Medan. Indonesian Trust Health Journal, 1(2), 61-67. https://doi.org/10.37104/ithj.v1i2.14

Thariq, A.S., Swastawati, F., \& Surti, T. (2014). Pengaruh perbedaan konsentrasi garam pada peda ikan kembung terhadap kandungan asam glutamat pemberi rasa gurih (umami). Jurnal Pengolahan dan Bioteknologi Hasil Perikanan, 3(3), 104-111.

Torres, C.A.R., Martinez, L.C., Guerrero, R.R., Vázquez, A.G.R., Solares, M.Z., Nosthas, L.C., \& Zúñiga, A.E.S. (2019). Design and implementation of modified-texture diet in older adults with oropharyngeal dysphagia: a randomized controlled trial. European Journal of Clinical Nutrition, 73(3), 989-996. https://doi.org/10.1038/s41430-019-0389-x

Viganó, P., Silva, N., Cremonezi, C., Vannucchi, G., \& Campanelli, M. (2011). Variation in the energy and macronutrient contents of texture modified hospital diets. Revista Chilena de Nutrición, 38(4), 451-457.

Wada, S., Kawate, N., \& Mizuma, M. (2017). What type of food can older Adults masticate?: Evaluation of mastication performance using color-changeable chewing gum. Dysphagia, 32(5), 636-643. 10.1007/s00455-017-9807-1

Xu, B.J., \& Chang, S.K.C. (2007). A comparative study on phenolic profiles and antioxydant activities of legumes affected by extraction. Journal of Food Science, 72(SI): 59-66. 10.1111/j.1750-3841.2006.00260.x 